\title{
Review of Business Strategies for Environmental Leadership and Sustainability Matters
}

\author{
Adegoke A. Isaiah \\ School of Business \\ Nanjing University Information Science and Technology, Nanjing, China
}

\begin{abstract}
Environmental leadership and sustainability has not much been pursued by most business organization in that, the main focus of most business organizations today is to make profit and to satisfy the customer. Modern business strategies demand the protection of the natural environment. Many people are now expecting corporate institutions to be socially responsible. Environmental deterioration caused by corporate activities is reducing the quality state of our environmental. Institutions must now develop strategies that can help protect and sustain the environment. There are many strategies firms can practice to sustain the environment. These strategies are known as Environmental business strategy. In the literature review two of these strategies were reviewed: Purchasing environmental strategy and Marketing environmental strategy.
\end{abstract}

Keywords: Sustainability, Strategies, marketing, Business Models, Environmental leadership

DOI: $10.7176 / \mathrm{JESD} / 12-2-04$

Publication date: January $31^{\text {st }} 2021$

\subsection{Introduction}

Formerly the notion of achieving sustainability was restricted to the minds of scientists, social leaders and visionaries. It entered the corporate domain, steadily. It is currently regarded as one of the most important aspects of any progressive and competitive company. Not only do renowned brands give sustainability the highest priority, but they also see it as a significant contributor to growth. The outlook of business around the world today has changed with rising environmental issues, strict rules and regulations combined with public awareness. Companies may play an important role in achieving sustainability by designing and implementing effective strategies and functions, such as green processes, product creation, energy conservation, etc. Nowadays, corporations face the challenge of environmental sustainability successfully.

Organizations face serious environmental problems today, including global warming, the oil crisis, water pollution etc. As society has advanced to prioritize environmental concerns, policymakers have also introduced more stringent environmental legislation. In response to pressures from different stakeholders, business organizations are more actively involved in modifying their policies in order to engage in quality environmental management and in-house green innovation programs to resolve environmental issues.

According to Wisner et al (2012), thought that pollution was concrete evidence of resource usage that was inadequate or inefficient. Many businesses have been driven to be low-carbon and environmentally proactive by carrying out green engineering activities to achieve a better balance of economic and environmental efficiency. The role of environmental leadership has been identified with the introduction of different environmental practices and the roles of top managers in fostering the sustainability of the environment (Boiral et al., 2014). Three phases are met by companies in implementing environmental policies. From compliance with eco-friendly environmental laws and environmental risk management to the production of sustainable and long-term strategies. Many industries have changed and many are turning towards more corporate priorities geared towards sustainability. Worrying events such as climate change, rising average temperatures and emissions of greenhouse gases are contributing to increasingly negative environmental and economic impacts that need to be effectively addressed (Papageorgiou et al., 2015). Businesses have faced a number of new obstacles in environmental management in recent decades. Moreover as customers demonstrate increased understanding of environmental issues and renewable energy sources, the need for environmentally friendly goods is increasingly imperative (Ntanos et al., 2016).

A number of researchers (Arabatzis et al., 2015) note that the inclusion of sustainable environmental management in the strategy of a company can be a key source of a competitive advantage that is the ultimate objective of each company. The current climate in which corporations are expected to work is very complicated, close to the atmosphere of a war. Operational research models have been developed for the study of such environments and can be applied in the case of businesses (Chalikias \& Skordoulis, 2014).

Many businesses have recognized that the introduction of sustainable business practices which leads to improved outcomes and creates new opportunities. Any company's first step towards sustainability is the need to comply with environmental legislation. Following national and international environmental legislation increases the environmental efficiency of the organization. Not only do certain firms comply with laws, but they also go a step further by implementing full sustainable development programs. 
Industries need to realize that there is a limit to natural resources such as water and power. When resources start to decline, the cost may grow and businesses will not be able to procure natural resources according to their needs over time. It is therefore the responsibility of any organization to safeguard these resources and to find alternate methods for producing its goods and services.

\subsection{Motivation for the Study}

It is important to ensure that all business aspects, such as the management of the product life cycle, activities, information and technology, are sufficiently efficient to protect the environment. Full environmental commitments and energy use requirements must be included in the company's overall policies to boost business performance. Inside the company's supply chain around the globe, environmental stewardship and energy saving push should be pursued. The most effective strategies of any company are strategies that promote cost reduction, increase operating and energy efficiency, lower air, water and soil pollution, and save natural resources (Arabatzis et al., 2015).

This article seek to answer the following question: What is environmental leadership and sustainability? What are some of the strategies business organizations can adopt to protect the environment? The destruction of our environment is increasing on an increasing rate. Adding to it, many organizations neglect the sustainability of the environment. It has now become the burden of government in all over the world to spend huge amounts of money to maintain the environments.

Most Corporations consciously focused only on the income element from the environment and neglecting the sustainability element of the environment. It is now therefore very expedient to raise the awareness about the responsibilities business organizations has to perform as far as environmental sustainability is concern irrespective of the line of production, whether manufacturing or service rendering. In undertaking such responsibilities, some business strategies were identified which can help business organizations to make profit and at the same maintain the natural discourse of the environment.

\subsection{Review of Environmental Business Strategies}

Green innovation practices have increasingly grown and acted as a bridge between the operations of businesses and the satisfaction of different stakeholders, including governments, clients, business partners, organizational workers and communities (DiPietro et al., 2013). However since Western economies are so deeply embedded in the conventional business model, incorporating these current social and environmental demands does not come easily.

Corporate environmentalism has two dimensions, according to Banerjee et al. (2003): environmental orientation, which is characterized as 'the acknowledgement of the significance of environmental issues facing their firms by managers' and environmental strategy, which can be interpreted as' the degree to which environmental issues are incorporated with the strategic plans of a firm. We discuss in this paper what businesses really do to be environmentally friendly, which suggests that we deal with environmental strategies and not environmental orientation. Similar to Banerjee et al. (2003), we address strategies on two organizational levels, i.e. the corporate level and functional level.

The highest organizational level of corporate strategy deals with the balance of the strategic business divisions of a corporation and the ties between these units (Wheelen \& Hunger, 2006). Therefore, corporate environmental strategies address the degree to which environmental concerns are incorporated into the decisions of such an organization regarding starting new companies, selecting technology, plant locations and investments in research and development (Banerjee et al., 2003). Functional-level methods answer strategic questions within various business functions (Wheelen \& Hunger, 2006). Therefore, Functional Environmental strategy addresses how environmental issues are included in long-term strategies within such business functions as procurement, manufacturing, marketing and staff. The environmental purchasing strategy includes long-term supply chain management practices aimed at stimulating recycling, reuse and resource reduction (Carter \& Carter, 1998). Likewise, Min and Galle (2001) describe green purchasing as environmentally conscious purchasing practices that minimize waste sources and facilitate recycling and the recovery of purchased inputs without adversely affecting the performance requirements of such inputs.

As for the environmental production strategy, Kleiner (1991) proposes that three basic issues should be answered by an organization wishing to be green: product preparation, disclosure policy, and initiatives for pollution reduction. Gupta (1995), on the other hand, argues that production/operations decisions where environmental concerns need to be taken into account include product planning, capability planning and scheduling, process design, labor force management, inventory management and quality management. The environmental marketing strategy encompasses all activities intended to create and promote any interaction aimed at meeting or wanting to meet human needs, stressing that these activities have the least possible negative effect on the natural environment (Stanton \& Futrell, 1987).

It is undisputable that, customers have to choose organic goods to competing non-green products if 
environmental marketing is to provide a competitive advantage (Polonsky et al., 1995). Finally, the staff environmental approach is connected to educating staff and raising their awareness of environmental concerns, allowing managers to increase the active participation of staff in environmental management systems activities (Čater et al., 2008b). Environmental management of human capital is very relevant because corporations are becoming more environmentally concerned in other aspects of their business activities by education and increased knowledge of employees. For the purpose of this research only two strategies are going to be discussed: Purchasing Environmental strategy and Marketing Environmental Strategy.

\subsection{Purchasing Environmental Strategy}

One of the easiest ways to positively impact the environment is through your purchasing decisions. Green Purchasing refers to the purchase of goods and services that, relative to competing products or services that serve the same function, have a lesser or lesser impact on human health and the environment. Green purchasing is also known as environmentally preferred purchasing (EPP), environmentally responsible purchasing, green procurement, affirmative procurement, eco-procurement, and environmentally responsible purchasing. Purchasing is one of the most strategic business processes used by many firms to carry out a variety of operations (Wu, 2008; Olaore \& Adebisi 2013). Selecting the right product that has no effect on the environment is very important. The selection of the right suppliers is also another essential activity that goes in a long way to protect our environment. In addition, buying can serve as a vital connection between supply sources and the organization itself.

In terms of discarded packaging materials, procurement may lead to an important environmental threat. Over time, the level of awareness of global warming and other environmental concerns has dramatically increased, leading businesses to "green" their purchases. Green purchasing takes into account environmental and social transparency in the purchase process ( $\mathrm{Wu}, 2008)$. Environmentally-conscious shopping programs include the purchase of goods and services that fulfill sustainability targets, such as reduced waste sources, recycling, reuse, reduction of energy and replacement of materials ( Min \& Galle, 2001). In a similar vein, ElTayeb et al. (2010) and Yang and Zhang (2012) argued that the practice of selecting suppliers that offer eco-friendly products and services is green purchasing.

Green purchasing seeks to reduce harmful impacts on the environment in method of production and transport by the use of durable, recyclable and reusable materials (Sarkar, 2012). Companies that adopted environmental buying policies benefited from cost savings, enhanced brand image and reduced liability (Wisner et al., 2012). Companies who have a competitive edge in their markets would be able to exploit their green supply base with lower prices, higher quality and concern about environmental aspects to influence their overall cost structure and product quality. Green buying or purchasing is s sustainable buying. They described green purchasing as a duty to promote sustainability and a significant relationship between product emphasis and the natural environment is considered to be sustainable. Based on the Green Buying Network International (IGPN) (2010) green purchasing is characterized as the purchase of any product and service which has a minimal effect on the environment and the use of comparable prices to demonstrate social responsibility and ethics. In order to buy a product or product, the buying department must strike a balance between quality, cost, features, and climate, social and ethical aspects.

In fact, in response to the increased concern about environmental sustainability, organizations adopt green buying strategies (Sarkar, 2012). This is because the green buying role requires the collection and procurement of green materials to fulfill the requirement for eco-friendly organizational goods. Some research have been done to explain the green purchasing behavior of businesses. One such analysis among US firms was undertaken by (Min $\&$ Galle, 2001). The research investigated the variables affecting the ability of a purchasing firm to follow a green buying strategy. The study's key finding is that a purchasing company with a large purchase volume is more interested in green buying practices. Again, green procurement is likely to be carried out by a buying company that takes environmental regulatory enforcement more seriously. Finally, businesses believe that high economic spending is the biggest barrier to green buying practices.

\subsection{Marketing Environmental Strategy}

While the word 'Green marketing also known as Marketing Environmental strategy' is commonly used these days but still lacks a single agreed meaning. Simula et al., (2009), claimed that the term' Green 'is now commonly used for emerging innovations and new goods that have a more sustainable environmental impact. Unfortunately most people assume that green marketing applies primarily to the promotion or advertisement of goods with environmental features. Terms such as Free of Phosphate, Recyclable, Refillable (Troumbis, 1991). Green marketing thus includes a wide variety of practices, including product alteration, manufacturing process improvements, packaging changes, as well as campaign modification. Defining green marketing, however, it's not an easy job. In reality, the terminology used in this field varies, including: green marketing, environmental marketing and environmental marketing.

Any of the aspects consumers most commonly equate with green marketing are Ozone Tolerant and Environmentally Friendly. In general, green marketing is a much broader definition, one that can be extended to 
consumer products, manufacturing goods and even services, although these terms are green marketing statements. For instance, there are resorts around the world that are starting to market themselves as "ecotourist" facilities i.e. facilities that "specialize" in experiencing nature or working in a way that minimizes their environmental impact. These practices include not only the creation of physical characteristics of goods which are not hazardous to the natural environment, but also procedures, advertising and associated arguments (Polonsky et al., 1995). Kotler (2000, p. 6) described marketing as a social mechanism through which individuals and groups receive what they need and want by producing.

In India, within the new market structure, green marketing is gaining importance. It allowed businesses to cobrand goods into a new line of business considered to be environmentally friendly products and services. According to Polonsky et al (1995), green marketing is also known as marketing for the environment or ecological marketing. As resources are exhausted every second and human appetite increases every minute, it is very important to decrease the waste of resources to protect the environment. The aim of green marketing is to minimize environmental damage and economic benefits as well (Kotler, 2000). These practices include not only the development of physical characteristics of goods which are not hazardous to the natural environment, but also the development of procedures, advertising and related arguments. Polonsky et al (1995, p.199) notes that the effect of green marketing is both internal and external, from the point of view of organizations. It affects the risks and opportunities for organizations in the external world, while it impacts the strengths and weaknesses of organizations in the internal environment. In addition, Ottman (2006) clarified that green marketing fulfills two goals: environmental quality improvement and consumer satisfaction.

Further Polonsky et al (1995), indicated that the purpose of green marketing is to inform and make people ready to go green because it affects people's life style and actions. There are steady public-interest campaigns and concerns regarding environmental issues. Companies such as BASF and DuPont are leading the heavy industry's greening and have had the largest effect on the environment. The words widely used to characterize the processes and goods of companies using less energy are 'Green',' Pro-environmental',' Sustainability',' Environmentally Friendly' and 'Ecology'; are recyclable; minimize waste and emissions and protect natural resources.

Green Marketing aims to bring green goods and services production, marketing, consumption and disposal activities to eliminate damage related to global warming, non-biodegradable solid waste, pollutants, etc. In order to eliminate damage related to global warming, non-biodegradable solid waste, pollutants, etc. It includes efforts to generate sensitivity between marketers and consumers towards green products and services in buses although the move to green business is initially costly, but with increasing consumerism, it may be beneficial in the near future (Ragavendra et Al, 2017). In this regard, it is the process of promoting any product on the basis of its environmental performance that seeks the requisite improvements (Charter \& Polonsky, 1999) Green Marketing has attracted new clients who are mindful of environmental sustainability and who choose green goods in their everyday lives (Pavan \& Mayal, 2010).

Ottman (1993), finds that green marketing strategies will help corporations earn more income and raise market share, and provide individuals with some personal benefits, such as incorporating their own values into the workplace. Kuhre (1995) proposed some more environmental marketing benefits, such as environmental change, reliable data, increased market share, reduction of trade barriers, standardization, lower impacts on health and safety, increased knowledge and interest, and enhanced relationships between the community and employees.

\subsection{Environmental Purchasing Strategy Model}

Environmental purchasing is the act of purchasing goods that are healthy the environment (Lee, 2009). Lee (2009), found that, the socially aware client feels strongly that he/she should do something about pollution and seeks to understand his/her purchasing behavior's social effect. A green consumer can be defined as one who avoids any product that can damage any living organism, caused environmental degradation during the development process or during the consumption process, consumes a large amount of non-renewable energy includes unethical testing on animals or human subjects (Elkington, 1994).

There are factors that influence the environmental behavior of a consumer. 
From the model below have: Environmental knowledge, Environmental awareness, Environmental concern Environmental beliefs and Environmental consciousness (Sarumathi, 2014).

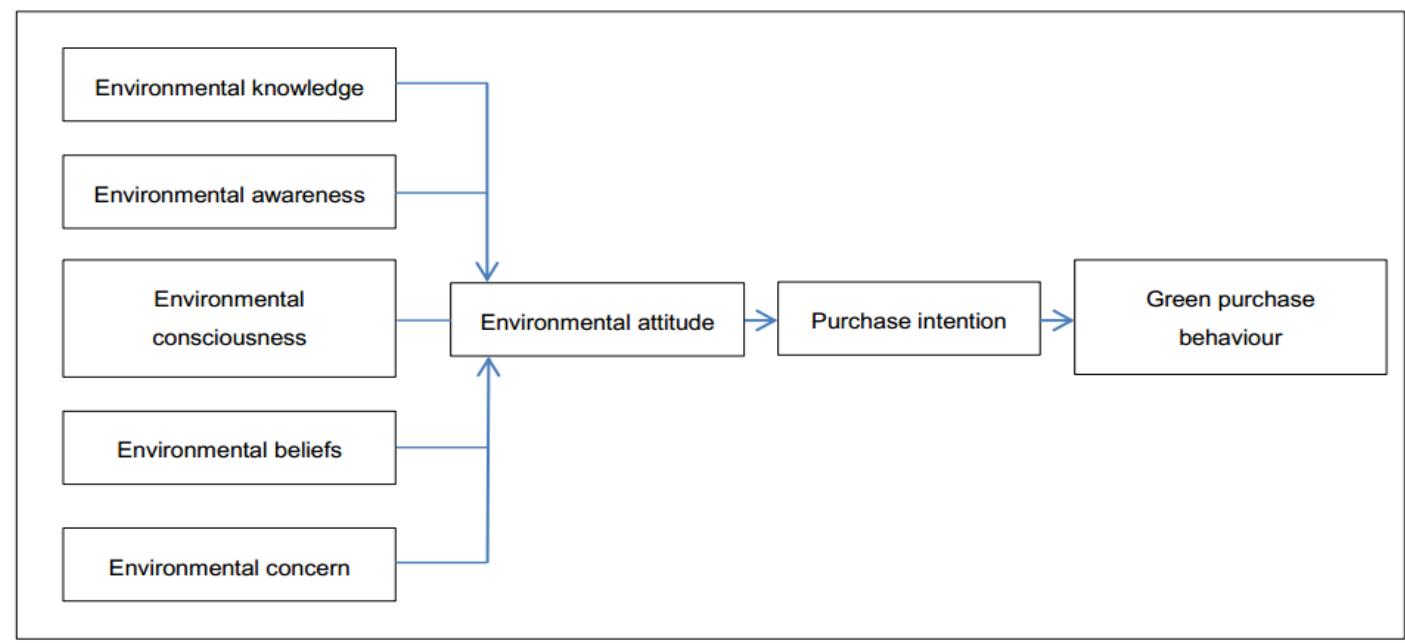

Source: Sarumathi (2014)

Figure 1: Conceptual Framework of Factors Influencing Green Purchase Behavior of Consumers

\subsection{Juslin's Model of Environmental Marketing}

Juslin (1992), provided an environmental marketing strategy that is focused on its integrated marketing planning model (Juslin, 1992). The notion behind this model is that, environmental issues should be appropriately integrated or contextualized in all the hierarchical levels of marketing planning. Such levels are marketing strategies, marketing structure and marketing functions. Environmental marketing expands the consumer ideology with clear targets and functions at the societal and company level.

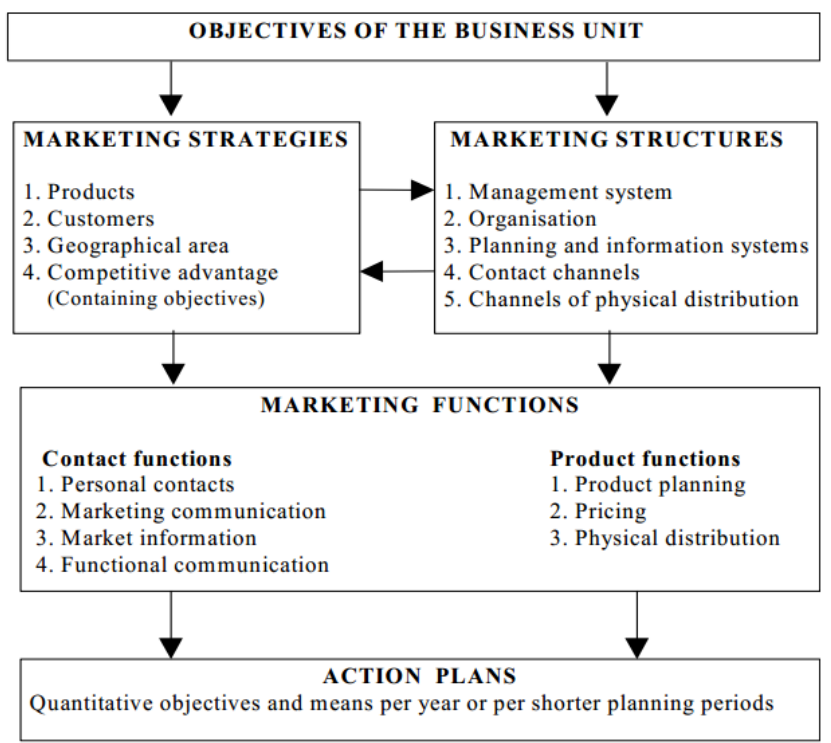

Figure 2: The Integrated Model of Marketing Planning (Juslin, 1992).

According to Juslin's (1992) strategic marketing planning model has three core areas with their variables:

1. Strategies (products, customers, market area and competencies),

2. Structures (organization, planning and information systems, contact channels and channels of physical distribution)

3. Functions (personal selling, marketing communication, market information, product planning, pricing, physical distribution).

\subsubsection{Marketing Strategies}

Environmental friendliness is viewed in environmental product decisions as a product characteristic that is examined over the entire life of the product. Environmental friendliness can also turn a commodity/ordinary product into a special or custom product which is reflected in the price. A business seeks to meet the needs of environmentally conscious consumers in environmental customer and market area decisions, and thus consciously 
attempts to concentrate on those market segments (Julin, 1992).

\subsubsection{Marketing Structures}

Marketing structures are the processes by which the organization's everyday work is carried out and form the basis for environmental marketing preparation and execution. Taking into account Management system, Organization, Contact channels, Channels of physical distribution, Planning and information systems.

3.1.3 Environmental Marketing functions

Perhaps the most visible aspect of environmental marketing is environmental claims in advertising. Green advertising, however, leads to "greenwashing" without reliable environmental focus in strategies and adequate relations between strategies and marketing operations (Julin, 1992). In order to support prudent strategic and structural decisions, a comprehensive compilation of appropriate market information about environmental issues in the markets would provide context information. Strategic choices should also reflect product planning and pricing (Julin, 1992).

\subsection{Evaluating of the Strategies}

\subsection{Analysis of the Purchasing Environmental Strategy.}

The practice of this model induces environmental sustainability as a culture among consumers. It is no more driven by an external force. Consumers become aware and sensitive to the dangers involve in environmental pollution due the rational in purchasing green products. This reduce the cost of government spending in trying to keep the environment since it has become the role if citizens rather than organizations.

It reduce government spending. Since consumers becomes self-conscious about the dangers involve in environmental degradation, government no longer spend much in shouldering environmental responsibilities. Citizens or consumers become role players themselves.

On the other hand, this model however have some few sets back. The focus is on the consumer and leaving the producer out. The focus of the Environmental Purchasing Strategy model is on the consumer gaining knowledge about purchasing green products in order to preserve the environment. The role of business organizations in producing green products and rendering environmental free services is absent in the model. Environment sustainability may fail if citizens don't have substitutes for goods and service in that of companies failed to produce green products, due to necessities, the consumer may have no alternative to purchase a product that will not preserve the environment. For example, monopolistic organizations that produce a particular kind of goods and service cannot give choice to consumers to make green decision since there might not be an alternative choice.

\subsection{Analysis of Juslin's Model of Environmental Marketing}

This model factors all the stages of production from the production stage to the consumption stage. Products are produce to be environmental friendly. Environmentally friendly goods keep the natural discourse of our society in line. The consumer is given satisfaction on product consumption. Another significance of this model is the continuous of green products. Green products preserve the health life of the consumer. In the long run, the consumer gets value for money. Environmental sustainability goes beyond the geographic elements of the cosmos. It includes the sustainability of human life. Most companies only focus on the end product. Just to get the product the consumer. However in Julin's model the mode of distribution is also key. The channel of distribution. Does the mode of distribution of the production cause of environmental pollution. The distribution of the goods must not endanger the environment.

Another advantage of Julin's model is the practice of management system. Environmental sustainability practices policies is contextualized in the companies policies. This therefor means, environmental sustainability has become a daily routine. Irrespective of the numerous benefits in Julin's Model of Environmental Marketing there are few cons. Such system is very expensive as compared to Environmental Purchasing Strategy. The model propels an organization to engage in green production and preserve the environment from the production stage until the goods reach the consumer. It burdens the organization to incur much cost.

In conclusion, each environmental business strategy model has the tendency of preserving and sustaining the environment. However Julin's model of Environmental Marketing Strategy Model should be preferred over Purchasing Environmental Strategy Model because the environmental sustainability is not only carried out by the consumer as seen in the purchasing but rather it covers every aspect of a business activity. Under Julin's model sustainability of the environment becomes the company's policy. At every stage of the business activity from the production stage to the distribution stage, the organization is very mindful about the preservation of the environment.

\subsection{Conclusion}

In modern business era, companies do not only face economic competition but also environmental and social demands. Our environment is blessed with many diverse resources therefor its protection and sustainability is key. 
Human life is dependent on the environment. Water resources, land resources and any other form of resource must be preserved not for present use but also for future use. Environmental leadership and sustainability has entered the corporate domain. Business entities are being hold accountable to preserve the environment by practicing green innovation strategies. In order to sustain the environment, some strategies are being identified: Environmental purchasing strategy and Environmental Marketing strategy. Each of these strategies has its own strength and weakness. However, the sustainability of the environment is paramount. It not the sole responsibility of government to preserve the environment in which we live. From the models discussed, both consumer and the producer has a role to play to preserve the environment. Institutions should inculcate the culture of environmental sustainability in their line of work.

\section{References}

Arabatzis, G., Galatsidas, S., Intze, C., Chalikias, M., Tsiantikoudis, S. \& Mamalis, S. (2015). Green Entrepreneurship and Green Products: Consumers' Views and Attitudes in Regional Unit of Evros. In: Proceedings of the 7th International Conference on ICT in Agriculture, Food and Environment (HAICTA 2015). Kavala, September 2015. Athens: HAICTA, pp. 291-297.

Brunnermeier, S. B., \& Cohen, M. A. (2003). Determinants of environmental innovation in US Manufacturing Industries. Journal of Environmental Economics and Management, 45(2), 278-293.

Banerjee, Subhabrata B. (2001), Corporate Environmental Strategies and Actions, Management Decision, 39 (1), 36-44

Boiral, O., Baron, C., \& Gunnlaugson, O. (2014). Environmental leadership and consciousness Development: A case study among Canadian SMEs. Journal of Business Ethics, 123(3), 363-383.

Charter M, Polonsky M.J. (1999). Greener Marketing: A Global Perspective on Greening Marketing Practice. Greenleaf Publishing

Carter, Craig R., and Carter, Joseph R. (1998), Inter organizational Determinants of Environmental Purchasing: Initial Evidence from the Consumer Products Industry, Decision Sciences, 29 (3), 659-684

Chalikias, M. \& Skordoulis, M. (2014). Implementation of Richardson's arms race model in advertising Expenditure of two Competitive Firms. Applied Mathematical Sciences. 8(81): 4013-4023

DiPietro, R. B., Cao, Y., \& Partlow, C. (2013). Green practices in upscale foodservice operations: Customer Perceptions and purchase intentions. International Journal of Contemporary Hospitality Management, 25(5), 779-796.

ElTayeb, T. K., Zailani, S. \& Jayaraman, K. (2010). 'The examination on the drivers for green purchasing Adoption among EMS 14001 certified companies in Malaysia', Journal of Manufacturing Technology Management, 21(2): 206-225.

Gupta, Mahesh C. (1995), Environmental Management and Its Impact on the Operations Function, International Journal of Operations \& Production Management, 15 (8), 34-51.

International Green Purchasing Network (IGPN) (2010). Green purchasing: The new growth frontier - Policies and programmes to enhance green business growth in Asia, Europe and the United States. Japan: International Green Purchasing Network, 1- 50.

John Elkington, the Green Consumer, Julia Hailes Penguin Books; First Edition 1994.

Juslin, H. 1992. Forest Products Marketing: A Theoretical Model and Its' Empirical Application. Case: The Finnish Forest Industry. In: Proceedings of IUFRO ALL Division 5 "Forest Products" Conference. August 23-28, 1992. Nancy, France.

Kuhre WL. 1995. ISO 14020s Environmental Labelling - Marketing. Prentice-Hall: Englewood Cliffs, NJ.

Kleiner, Art (1991), What Does It Mean to Be Green? Harvard Business Review, 69 (July-August), 4-11. Kaman Lee, (2009) "Gender differences in Hong Kong adolescent consumers' green purchasing behavior", Journal of Consumer Marketing, Vol. 26 pp.8796

Kotler, P. (2000), Marketing Management: The Millennium Edition, Prentice-Hall, Englewood Cliffs, NJ.

Min, H. \& Galle, W. P. (2001). 'Green purchasing practices of US firms', International Journal of Operations \& Production Management, 21(9), 1222-1238.

Ntanos S., Ntanos A., Salmon I. \& Ziatas T., (2016). Public awareness on Renewable Energy Sources: a Case study for the Piraeus University of Applied Sciences. In: Proceedings of the 5th International Symposium and 27th National Conference on Operational Research (EEEE2016). Athens, Piraeus University of Applied Sciences, pp. 18-23.

Olaore, R. A. \& Adebisi, N. T. (2013). 'Accounting, purchasing and supply chain management interface', IOSR Journal of Business and Management, 11(2), 80-84.

Pavan Mishra and Payal Sharma (2010). Green marketing in India: Emerging Opportunities and Challenges. Journal of Engineering, Science \& Management Education, 3, 9-16.

Papageorgiou, A., Skordoulis, M., Trichias, C., Georgakellos, D. \& Koniordos, M. (2015). Emissions Trading scheme: Evidence from the European Union Countries. In: Communications in 
Polonsky, J., M. Alma, T., M. \& Mintu, W. (1995), Environmental Marketing: Strategies, Practices, Theory, and Research. Newyork: The Haworth Press, Inc

Raghavendra, B. Ramesh, E. \& Rajesh, E. (2017). Green Marketing in India. 9th International Conference on Recent Innovations in Science, Engineering and Management, Dhruva.

Rajan, A. J., Ganesh, K. \& Narayanan, K. V. (2010). 'Application of integer linear programming model for Vendor selection in a two stage supply chain', Proceedings of the 2010 International Conference on Industrial Engineering and Operations Management. 9-10 January. Dhaka,

Sarkar, A. N. (2012). 'Green supply chain management: A potent tool for sustainability green marketing', AsiaPasific Journal of Management Research and Innovation, 8(4), 491-507.

Simula, H., Lehtimark, T., \& Salo, J. (2009), Managing Greenness, Journal of systems and Information Technology, 11(4), 331-346.

Stanton, William J., and Futrell, Charles (1987), Fundamentals of Marketing, New York: McGraw-Hill.

Sarumathi, S. 2014. Green purchase behavior: A conceptual framework of socially conscious consumer behavior. Global journal of financial management, 6(8):777-782.

Wang, Y.; Li, Y.; Zhang, J.; Su, X. How impacting factors affect Chinese green purchasing behavior based on Fuzzy Cognitive Maps. J. Clean. Prod. 2019, 240, 118199.

Wang, Y.; Li, Y.; Zhang, J.; Su, X. How impacting factors affect Chinese green purchasing behavior based on Fuzzy Cognitive Maps. J. Clean. Prod. 2019, 240, 118199.

Troumbis, A. Y. 1991. "Environmental Labelling on Services: The Case of Tourism." Ekistics (348/349): 167173.

Wisner, J. D., Tan, K-C. \& Leong, G. K. (2012). Supply Chain Management: A Balanced Approach, third Edition, Canada, South-Western Engage Learning.

Wu, Y. (2008). Green Purchasing to Achieve Corporate Sustainability. Master Thesis for Lumes Lund University. Wheelen, Thomas L., and Hunger, David J. (2006), Strategic Management and Business Policy, Upper Saddle River: Pearson - Prentice Hall. 